\title{
Ultrastructural characterisation of the $M$ protein in nerve biopsy of patients with POEMS syndrome
}

\author{
David Adams, Gérard Said
}

\begin{abstract}
To learn more about the mechanisms of nerve lesions in POEMS syndrome, nerve specimens from four patients were studied with an immunogold method at the ultrastructural level to detect and localise the $M$ protein in the different nerve compartments. An indirect immunolabelling technique was applied on 4\% PFA fixed and LR White embedded nerve specimens. Antisera against IgG, IgA, IgM, and lambda and kappa light chains were used as primary antisera. Morphological studies disclosed an important axonal loss in association with the demyelinative process. Endoneurial deposits of immunoglobulins were found in all cases. In the patient with the most severe form of neuropathy, diffuse deposits were present in the endoneurial space, especially in the subperineurial area. In the other patients, occasional deposits of the $M$ protein were found in the myelin sheath $(n=2)$; or between cells $(n=1)$. No deposit was found in the axons. The class of the $M$ protein labelled in the nerve corresponded to that detected in the serum in three of four patients, with labelling of two heavy chains in one patient. Immunolabelling of the $M$ protein on the myelin sheath, Schwann cells, and in the endoneurial space favour a direct role of the $M$ component in the lesions of nerve fibres, and justify active treatment of the plasmacytic proliferation.

(尹 Neurol Neurosurg Psychiatry 1998;64:809-812)
\end{abstract}

Service de Neurologie

Ranvier, Centre

Hospitalier de Bicêtre,

Université Paris XI

D Adams

G Said

Correspondence to:

Dr D Adams, Centre

Hospitalo-Universitaire de

Bicêtre,

78 rue du Général Leclerc, 94275 Le Kremlin-Bicêtre Cedex, France. Fax 0033 45212853.

Received 25 July 1997 and in revised form 19 November 1997

Accepted 25 November 1997 mains unclear. It is tempting to suspect a role for the monoclonal protein because improvement of the neuropathy had been reported in some patients after treatment of solitary plasmacytoma by radiotherapy or surgery ${ }^{267}$ even if deposits of $M$ protein in the nerve had been only once ${ }^{5}$ reported in cases of POEMS syndrome by light immunocytochemical study. ${ }^{489}$ To learn more on the subject, we tried to detect the $M$ protein in nerve compartments from patients with POEMS syndrome by using a method of immunoelectron labelling and protein A gold complex that we have found to be both specific and sensitive in the study of amyloid deposits in amyloid neuropathies. ${ }^{10}$ Such an approach has been used in a few peripheral neuropathies associated with monoclonal IgM M protein. ${ }^{11-14}$

\section{Patients and methods}

Between July 1991 and November 1992, we investigated four patients who manifested signs and symptoms characteristic of POEMS syndrome (table). Three patients (patients 1, 2, and 4) had a progressive sensorimotor polyneuropathy that predominated in the lower limbs. Patient 3 had a sensory polyneuropathy. Neuropathy was the presenting manifestation in all cases; the interval between the first manifestations of neuropathy and performance of the nerve biopsy ranged from a few months to five years. Organomegaly and different manifestations of endocrinopathy were present in all four patients. Skin changes were found in patients $1-3$. In patient four an osteosclerotic plasmacytoma of the spine had been removed and irradiated two years before. Monoclonal gammopathy was IgA lambda in two cases, IgG lambda in one, and IgG kappa in 1. Radiographic skeletal surveys were normal in three cases and showed a diffuse osteoporosis in one. The proportion of plasma cells in bone marrow aspiration varied from 3 to $5 \%$ in patients 2,3 , and 4 , to $22 \%$ of atypical plasma cells in patient 1 .

\section{MORPHOLOGICAL AND IMMUNOPATHOLOGICAL} STUDIES

In all patients the superficial peroneal nerve was biopsied under local anaesthesia after they had given informed consent. All nerve 
Main characteristics of POEMS syndromes studied and results of ultrastructural immunocytological study in neuropathies of POEMS syndrome

\begin{tabular}{|c|c|c|c|c|c|c|c|c|c|c|c|}
\hline \multirow[b]{3}{*}{ Case } & \multirow{3}{*}{$\begin{array}{l}\text { Age } \\
\text { Sex }\end{array}$} & \multirow{3}{*}{$\begin{array}{l}\text { Neuropathy } \\
\left.\text { (weakness }{ }^{\star}\right)\end{array}$} & \multirow{3}{*}{$\begin{array}{l}\text { Serum } M \\
\text { protein } g / l\end{array}$} & \multirow{3}{*}{$\begin{array}{l}\text { Bone marrow } \\
\text { aspiration \% } \\
\text { plasma cells }\end{array}$} & \multirow[b]{3}{*}{ Other manifestations } & \multicolumn{6}{|l|}{ Ultrastructural immunocytological study } \\
\hline & & & & & & \multirow[b]{2}{*}{ Location } & \multicolumn{5}{|c|}{ Immunoglobulin deposits } \\
\hline & & & & & & & $\operatorname{Ig} G$ & $\operatorname{Ig} A$ & $\operatorname{Ig} M$ & kappa & lambda \\
\hline 1 & $\begin{array}{l}79 \\
M\end{array}$ & $\begin{array}{l}\text { Sensorimotor } \\
\text { (arms: distal 3/5 } \\
\text { legs: distal: } 2 / 5 \\
\text { proximal: } 3 / 5 \text { ) }\end{array}$ & $\begin{array}{l}\text { IgG } \\
\text { Kappa } \\
26 \\
(\mathrm{~N}<12.5)\end{array}$ & $\begin{array}{l}22 \% \\
\text { atypical cells }\end{array}$ & $\begin{array}{l}\text { Skin } \\
\text { Thickening } \\
\text { Hypothyroidism } \\
\text { Generalised } \\
\text { Lymphadenopathies }\end{array}$ & $\begin{array}{l}\text { Endoneurium } \\
\text { Subperineurium } \\
\text { Between cells }\end{array}$ & +++ & - & Not done & +++ & - \\
\hline 2 & $\begin{array}{l}72 \\
F\end{array}$ & $\begin{array}{l}\text { Sensorimotor } \\
\text { (legs: distal: } 3 / 5 \text { ) }\end{array}$ & $\begin{array}{l}\text { IgA } \\
\text { Lambda } \\
3.6 \\
(\mathrm{~N}<3.1)\end{array}$ & $5 \%$ & $\begin{array}{l}\text { Hyperpigmentation } \\
\text { Hypothyroidism } \\
\text { Hepatomegaly } \\
\text { Generalised } \\
\text { Lymphadenopathies } \\
\text { Peripheral oedema }\end{array}$ & Around an endoneurial cell & - & + & - & - & + \\
\hline 3 & $\begin{array}{l}78 \\
M\end{array}$ & $\begin{array}{l}\text { Sensory } \\
\text { (none) }\end{array}$ & $\begin{array}{l}\text { IgG } \\
\text { Lambda } \\
18.5 \\
(\mathrm{~N}<12.8)\end{array}$ & $5 \%$ & $\begin{array}{l}\text { Hypertrichosis } \\
\text { Gynaecomastia }\end{array}$ & In the myelin sheath in one fibre & + & - & - & - & + \\
\hline 4 & $\begin{array}{l}49 \\
M\end{array}$ & $\begin{array}{l}\text { Sensorimotor } \\
\text { (legs: distal: } 4 / 5 \text { ) }\end{array}$ & $\begin{array}{l}\text { IgA } \\
\text { Lambda } \\
4.3 \\
(\mathrm{~N}<3.4)\end{array}$ & $3 \%$ & $\begin{array}{l}\text { Impotence } \\
\text { Hepatosplenomegaly }\end{array}$ & Endoneurium in the myelin sheath & + & + & - & - & + \\
\hline
\end{tabular}

^Paresis graded according to MRC scale from 0 to 5 .

specimens were fixed in buffered $3.6 \%$ isotonic glutaraldehyde at $\mathrm{pH} 7.4$, then divided into four parts. One fragment was embedded in paraffin, cut at $6 \mu \mathrm{m}$ thickness, and examined after haematoxylin and eosin staining. The second fragment was embedded in epon. Thionin stained $1 \mu \mathrm{m}$ thick transverse sections were used for morphometry and $0.3 \mu \mathrm{m}$ thick sections stained with uranyl acetate and lead citrate for electron microscopic examination. The third fragment was postfixed in osmium tetroxide, then macerated in $66 \%$ glycerine for 48 hours before dissection in pure glycerine.

The density of myelinated fibres $/ \mathrm{mm}^{2}$ was determined on the whole intrafascicular area. One hundred consecutive fibres were isolated over more than 10 internodes and classified according to their morphology into normal fibres; fibres showing segmental abnormalities of myelination; and fibres showing Wallerian degeneration, with the presence of a continuous row of ovoids and balls of myelin debris that decrease in size with time.

Another fragment was immediately fixed in a solution of $4 \%$ paraformaldehyde with $0.2 \%$ of glutaraldehyde for ultrastructural immunohistochemical study as previously described. ${ }^{10}$ Rabbit polyclonal antisera against the following antigens were used: human kappa or lambda light chains, and gammaglobulins IgM, IgG, and IgA (Biolyon, France).

\section{Results}

MORPHOLOGICAL STUDIES

Study of the nerves sections embedded in paraffin showed occasional endoneurial mononucleated cells in one patient; no amyloid deposits or vasculitis was seen. The density of

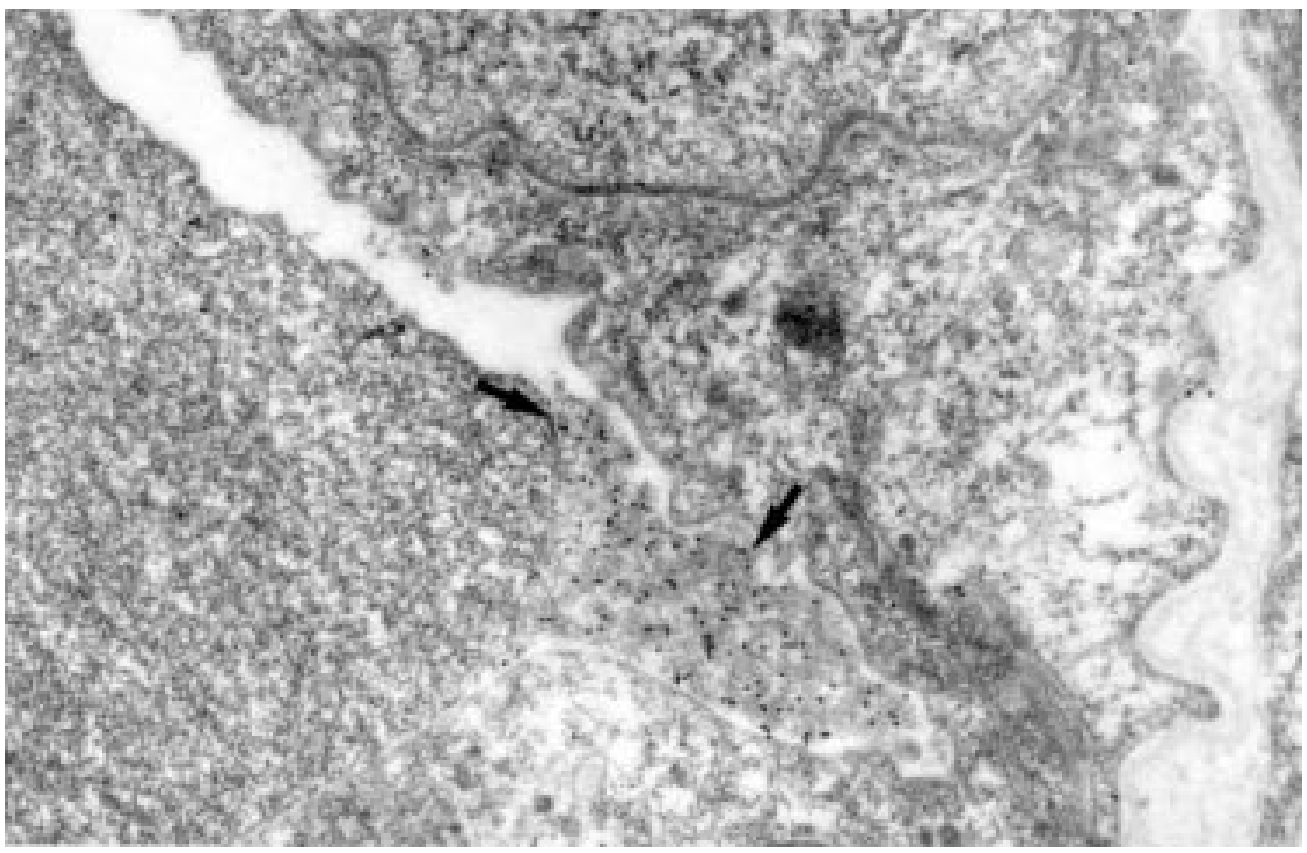

Electron micrograph of a cross section of the biopsy specimen of the superficial peroneal nerve from patient 1 with POEMS syndrome and serum IgG kappa. Immunogold reaction for IgG heavy chain between endoneurial cells (diameter of colloidal gold particles: $15 \mathrm{~nm}$ ) (arrows) $\times 13000$. 
myelinated fibres was reduced in all patients. It was $380,2670,2840$, and $3840 / \mathrm{mm}^{2}$ of endoneurial space in patients $1-4$ respectively, compared with around $7500 / \mathrm{mm}^{2}$ in controls of the same age group. Mild endoneurial oedema was present in nerve specimens from patients 1 and 3 on $1 \mu \mathrm{m}$ thick sections. On teased fibre preparations, the percentages of normal fibres were 20 in patient 1,20 in patient 2,86 in patient 3 , and 89 in patient 4 . The percentages of fibres showing segmental abnormalities of the myelin sheath were 20 in patient 1,32 in patient 2,8 in patient 3 , and 6 in patient 4 , whereas that of fibres at different stages of Wallerian degeneration were 60 in patient 1,48 in patient 2,6 in patient 3 , and 5 in patient 4 . Only 10 fibres could be isolated from the nerve specimen of patient 1 because of the intensity of axon loss, making the evaluation of abnormalities of isolated fibres less accurate than in the other patients.

IMMUNOPATHOLOGICAL STUDIES

On electron microscopical examination, endoneurial immunoglobulins were detected in all patients with POEMS syndrome studied (table). The class of the immunoglobulin (heavy and light chains) characterised corresponded in three of four cases to the monoclonal protein identified by serum immunoelectrophoresis and immunofixation. In patient 4 , we found a labelling for the heavy chains IgG and IgA whereas the $M$ protein identified in the serum was of IgA lambda type. The quantity and localisation of immunoglobulin deposits varied. In patient 1 , who had the most severe form of neuropathy, immunoglobulin deposits were abundant and diffuse in the endoneurium, the subperineurial space, and between the cells (figure). In the other patients, there were few deposits. They had been identified in the myelin sheath on one fibre in two cases and were located only around an endoneurial cell in one. No deposit was present in the axons. The ultrastructure of nerve specimens labelled for immunoglobulin was preserved and endoneurial cells, myelin sheath, and axons were clearly identified.

\section{Discussion}

The pathological findings in the four patients included in this study illustrate the range of morphological abnormalities found in the POEMS syndrome. Although demyelination of peripheral nerve fibres is a constant finding, both teased fibre preparations and quantitative evaluation of the density of nerve fibres on cross sections of epon embedded specimens demonstrate the important involvement of axons in all our patients with an almost complete axon loss in patient 1 , in keeping with its most severe neurological deficit. In this patient too, single fibre analysis showed a progressive neuropathy with most of the few remaining fibres undergoing axonal degeneration.

The presence of immunoglobulins was detected in the endoneurium on LR White resin embedded specimens in all our patients, by contrast with light microscopical immunopathological studies, ${ }^{4589}$ where it has been reported only once. ${ }^{5}$ Some arguments are in favour of a possible pathogenic role for the $M$ protein in the neuropathy of the POEMS syndrome. The class of monoclonal immunoglobulin found in the nerve correlated in three out of four patients with the type of $M$ protein detected in the serum. Some correlation was found between the abundance of immunoglobulin deposits in the nerve and the severity of the neuropathy. Important deposits were labelled in the endoneurium of patient 1 who had the most severe neuropathy. By contrast, only few deposits of immunoglobulins were found in nerve specimens from patients $2-4$, who had a milder neurological deficit and axon loss. The improvement of the neuropathy occurred in parallel to the reduction of the serum $M$ protein concentration by chemotherapy in patient 2 , but was less obvious in the others.

We used a special processing for the tissue different from that of the few immunoelectron microscopical studies of peripheral neuropathies. ${ }^{11-14}$ Embedding nerve samples in LR White resin after a fixation in paraformaldehyde allowed us to preserve a good antigenicity as shown in a previous study labelling amyloid fibrils in amyloid neuropathies. ${ }^{10}$ The preservation of ultrastructure was inferior to that obtained by classic ultrastructural studies, probably due to hydrophilic properties of the LR White resin.

If $M$ protein plays a pathogenic part, it is possibly via an autoimmune process and an antibody activity against a component of the peripheral nerve. This immunohistochemical study did not allow the localisation of this "antigen" formally as the site of immunoglobulin deposits varied. The presence of progressive demyelinative lesions as detected by single fibre analysis in most patients studied and the finding of $\mathrm{M}$ protein deposits in the myelin sheath in two patients are compatible with primary lesions of the Schwann cell-myelin complex. By contrast with neuropathies associated with IgM M proteins where antibodies against myelin associated glycoprotein (MAG) are characterised in more than $50 \%,{ }^{15}$ no antibody activity against $\mathrm{MAG}^{16}$ or other peripheral nerve antigens has been identified by immunoassays in serum samples from patients with POEMS. ${ }^{4}$ For the hypothesis of a pathogenic role of immunoglobulin, nerve lesions could be secondary to activation of the alternative pathway of the complement and to the "membrane attack complex". ${ }^{17}{ }^{18}$ This hypothesis could be also confirmed by ultrastructural immunolabelling.

We thank Mrs Arlette Durand for her technical assistance.

1 Bardwick PA, Zvaifler NJ, Gill GN, et al. Plasma cell dyscrasia with polyneuropathy, organomegaly, endocrinopathy, $M$ protein, and skin changes : the POEMS syndrome. Medicine 1980;59:311-22.

2 Nakanishi T, Sobue I, Toyokura Y, et al. The Crow-Fukase syndrome: a study of 102 cases in Japan. Neurology 1984;34:712-20. 
3 Ohi T, Kyle RA, Dyck PJ. Axonal attenuation and secondary segmental demyelination in myeloma neuropathies. Ann Negmental demyelination $1985 ; 17: 255-61$.

4 Donaghy M, Hall P, Gawler J, et al. Peripheral neuropathy associated with Castleman's disease. F Neurol Sci 1989;89: 253-67.

5 Gherardi R, Baudrimont M, Kujas M, et al. Pathological findings in three non-Japanese patients with the POEMS syndrome. Virchows Archiv A Pathological Anatomy 1988; 413:357-65.

6 Mahieux F, Baudrimont M, Fenelon G, et al. POEMS guéri par le traitement radical d'un plasmocytome. Rev Neurol 1991;147:231-3.

7 Miralles GD, O'Fallon JR, Talley NJ. Plasma-cell dyscrasia with polyneuropathy: the spectrum of POEMS syndrome. N Engl f Med 1992;327:1919-23.

8 Pareyson D, Marazzi R, Confalonieri P, et al. The POEMS syndrome: report of six cases. Ital $\mathcal{F}$ Neurol Sci 1994;15: 353-8.

9 Vital C, Gherardi R, Vital A, et al. Uncompacted myelin lamellae in polyneuropathy, organomegaly, endocrinopa-
thy, M-protein and skin changes syndrome. Acta Neuthy, $M$-protein and ski
ropathol 1994;87:302-7.

10 Adams D, Said G. Ultrastructural immunolabelling of amyloid fibrils in acquired and hereditary amyloid neuropathies. I Neurol 1996;243:63-7.
11 Mata M, Kan SN, Fink DJ. A direct electron microscopic immunocytochemical study of IgM paraproteinemic neuropathy. Arch Neurol 1988;45:693-7.

12 Yee WC, Hahn AF, Hearn SA, et al. Neuropathy in $\operatorname{IgM} \lambda$ paraproteinemia immunoreactivity to neural proteins and chondroitin sulfate. Acta Neuropathol 1989;78:57-64.

13 Lach B, Rippstein P, Atack D, et al. Immunoelectron microscopic localization of monoclonal IgM antibodies in gammopathy associated with peripheral demyelinative neuropathy. Acta Neuropathol (Berl) 1993;85:298-307.

14 Vital A, Vital C. Immunoelectron identification of endoneurial IgM deposits in four patients with Waldenström macroglobulinemia: a specific ultrastructural pattern related to the presence of cryoglobulin in one case. Clin Neuropathol 1993;12:49-52.

15 Quarles RH. Myelin-associated glycoprotein in demyelinating disorders. Crit Rev Neurobiol 1989;5:1-28.

16 Hafler DA, Johnson D, Kelly JJ, et al. Monoclonal gammopathy and neuropathy: myelin-associated glycoprogammopathy and neuropathy: myelin-associated glycopro36:75-8.

17 Mayer MM, Michaels DW, Ramm LE, et al. Membrane damage by complement. Crit Rev Immunol 1981;2:133.

8 Hiemstra PS, Biewenga J, Corter A, et al. Activation of complement by human serum IgA, secretory IgA and IgA 1 fragments. Mol Immunol 1988;25:527-33.

\section{HISTORICAL NOTE continued}

The researches of Brown Sequard and Kussmaul suggested that convulsions may take origin in the pons and medulla, having shown that they occur when other parts of the brain had been removed. Nothnagel had referred to "the convulsive centre" adjacent to the centre for respiration. Hammond too, thought the seat of epilepsy lay in the medulla, and that the demonstrated lesions in the cortex of certain epileptics excited the medulla to produce the convulsive fit.

By contrast, Gowers, although acknowledging the prevailing ambivalence, clearly favoured the cortex as the essential source of epilepsy:

"On the other hand, of all the regional diseases of the brain, lesions of the convolutions stand incomparably first as a cause of convulsions, and the experiments of Ferrier and Luciani also demonstrate that irritation of the cortex in the motor region has the same effect. ... The teaching of experiment, then is that both the cortex and the medulla (sic) may originate convulsions. The teaching of pathology is, as Wilks long ago insisted, that epileptiform convulsions have, in most cases, their origin at the surface of the brain." ${ }^{3}$

It was left to Jackson, Ferrier, and Horsley to show the primacy of the cortex in epilepsy.
Van der Kolk's work was not confined to the brain and mind. Brown-Séquard ${ }^{4}$ refers to his description of "very minute longitudinal white columns surrounded by gray substance in the cord, first described by Lockhart Clarke, . . . channels for sensitive impressions or for the orders of the Will to muscles." In Lecture 5. Brown-Séquard refers to the mysteries of decussating fibres from the posterior roots that "pass from one lateral half of the cord into the other one", an observation already made by this brilliant Dutchman, and several others.

J M S PEARCE 304 Beverley Road, Anlaby,

East Yorkshire HU10 7BG, UK

1 Haas LF. Jacobus Ludovicus Shroeder van der Kolk (17971862). F Neurol Neurosurg Psychiatry. 1994;57:1164.

2 Fine EJ, Fine D. FS van der Kolk's influence on American concepts of epilepsy. Proceedings of the 2nd meeting of the International Society for the History of the Neuro Sciences. Leiden: IJHNS, 1997:29.

3 Gowers WR. Epilepsy and other chronic convulsive diseases: their causes, symptoms and treatment. London: William Wood, 1885:167-75.

4 Brown-Sequard CE. Course of lectures on the physiology and pathology of the central nervous system. Philadelphia: Collins, 1860 , Lecture 2 p 24 , lecture 5 p 54 